\title{
Editorial:
}

\section{Issues of Decolonisation and Africanisation in Southern Africa}

\author{
Vivian Ojong \\ ORCID iD: https://orcid.org/0000-0001-7214-3949
}

\author{
Andy Chebanne \\ ORCID iD: https://orcid.org/0000-0001-5393-1771
}

\section{Maheshvari Naidu \\ ORCID iD: https://orcid.org/0000-0003-0398-3834}

\section{Introduction}

This volume of AlterNation presents articles that respond to the theme of the special volume which are issues of Decolonisation and Africanisation in Southern Africa. The two guiding terms, Decolonisation and Africanisation, entail processes that must be put in place to liberate Africa from colonialism and neocolonialism, which have deeply afflicted Africa and its people. There is considerable literature illuminating how each of these concepts 'Decolonisation and Africanisation' impact on knowledge production. Despite their individual impact and influence, specific attention has not been paid on how these twin terms are connected intricately in the Southern African context. This focused volume highlights some perspectives on issues of decolonization alongside the unfolding action of Africans on the colonial project (Africanization).

Decolonization is a necessary agenda to ensure that Africa can embark on Africanization in an authentic and visionary manner. This agenda is critical. We saw from African postcolonial experiments in the 1960s and 1970s, that decolonization and Africanization was the same thing; with decolonization being part of nation-building (Mbembe 2016). 'Seeing ourselves clearly' 
according to Ngũgĩ wa Thiongo's decolonial understanding (Decolonizing the Mind 1981), and 're-centering' the African position of 'seeing ourselves clearly' should go hand-in-glove with infusing ourselves at the centre of the knowledge generated (Africanization). This special issue gives us adequate room to engage with the two positions without collapsing them and forcing a narrow understanding.

This special issue is located within a south-south collaborative initiative between the University of KwaZulu-Natal and the University of Botswana, and looks at issues that shape and inform both research and curriculum in Southern African contexts, including the epistemic violence and hegemony that encircles research and teaching in Higher Education, as well as reminding us of internal structural coloniality in the guise of so called tradition and traditional values and expectation of women. This special issue sought papers that attempt to 'tease out' the multiple strands in the Africanization, coloniality, and decoloniality discourse, and sought to allow the 'blind spots' to begin to show. In 'troubling' and problematizing the notion of Africanization, we also 'trouble the notion of who and what being African is, and the complex nature of social identities'.

The editors invited both theoretical as well as empirical and descriptive papers that sought to engage critically and grapple with the variously positioned poly-vocal meanings of Colonialism/s and Postcolonialism, and Decolonization and Africanization, specifically within the geo-political Southern African space. Papers included, but were not restricted to, * Migrated African Archives: What does this Mean for 'African' Research? * African Feminism/s: Teaching \& Researching within African Feminist Paradigms * Issues of Post-colonialism/s, Nationalism/s and Identity* Africanization of the Curriculum and * Complexities in Teaching and Researching.

When the editors of this special volume called for contributions, they raised key questions that invited authors to interrogate issues of decolonization and means by which Africanization could be achieved. The salient questions that were raised were: What are the limits placed on the 'decolonization' project by the forces of neoliberalism? How are the latter affecting the future of the university? Is 'decolonization' the same as 'Africanization', as some African scholars have opined (Mbembe 2016)? These probing questions focused reflections and provided the fuel to engage the decolonization debate as it pertains to Southern Africa. Further, these interrogations are no less factual today than when they were uttered in 2016 by the erudite scholar known 
for not mincing his words, Achille Mbembe. This is much so because it looks like Africa is ever in a crisis mode - crises of culture and identity, political and economic crises, and educational and philosophical crises. African scholars in the Mother Continent and in the diaspora seem to be persuaded that the root cause of these ramifies and the intricate crises is colonialism (Mbembe 2016; Oelofsen, Riana. 2015; Fanon, 21952 [2008]); wa Thing'o, 1982). The epistemic crisis wrought by colonization and the manifold treacherous practices of neocolonisation continue to preserve cognitive injustices or the refusal to recognise the diverse ways through which different African people make sense of their world and their lives.

Neocolonisation is a reality in Southern Africa and across the continent of Africa. It takes insidious forms and often it is peddled by African governance systems. Neocolonisation creates a condition that Loomba (2015) equates to colonialism, and this leaves the African society in its wretched and pitiful condition (Frantz Fanon [1961] 2005). Assuming these gloomy realities of Africa in the post-colony, what does decolonization mean and what shape does decolonization and Africanization take in our institutions of research and teaching? Do we have the courage to confront and dismantle the dominant narrative that may well seek to silence the minority voices in the 'decolonization agenda', thereby perpetuating the very hegemony that needs to be disassembled? In the 1960s African leaders attempted to respond to these questions using diverse socio-political means. Kwame Nkrumah (1964) tried with pan-africanization (Poe, 2010), but he was quickly toppled from power and the project fell on the way side. Julius Nyerere (Otunnu 2015), ideologically an African nationalist and African socialist, promoted a political philosophy known as Ujamaa (cooperative economy conceptualized from an African socialism perspective) predicated on the use of an African language (Kiswahili) as the medium of rethinking African-ness, and authenticity, tried but for all that we know he did not get the support of his peers. It is not that Africans have no ideas. However, there seem to be no coordinated means to deliver Africanization. This in turn raises the question as to whether this is what is needed or should even be envisaged. Can there even be such a singularity that would not erase the rich polyvocality of the African identity? The answer to this exists along both ends of the spectrum as well as along the length of the spectrum itself.

Some may argue that the linguistic silos that exist according to colonial masters are an African example of lack of vision in the agenda for 
Africanization. Some may assert that the African Union is not even unanimous about how Africanization can be achieved. Different regions of Africa that make the African Union have different cultural persuasions that they may not have a unitary Africanization agenda. Others will hold that Africanization does not entail a collapse into a unitary Africanized agenda in any event.

Consequently, the decolonization project is complex and something that African leaders have difficulty to grasp. It is equally complex for scholars. This makes a demonstration of the polyvocality of the issues around this intricate theme, and illustrates how these impact Africans in the post or neocolonial era. The whole of African societal experiences in all domains, as accounted from all perspectives and disciplines, help to capture both the excitement and trepidations that exist in post colonialism and in neocolonialism. The Decolonization/Africanization approach, as attested by the solid contributions in this volume, can come from a variety of disciplines and perspectives: anthropological, economic, educational, philosophical, historical, sociological, psychological, and political.

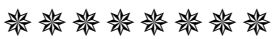

Berrington Xolani Ntombela's article looks at, 'The Urgency of Decolonization from an African Student's Perspective' through students' uprising in South Africa as associated with dissatisfaction in the educational system in general. The author argues that the Soweto uprising was a resistance on the imposed Afrikaans as the medium of instruction, and views the recent university students protests on the continued issue of Cecil Rhodes statue at the centre of the University of Cape Town as a precursor of the \#FeesMustFall which also responded to the subtle exclusionist agenda for the majority of Africans who were barred constantly from accessing top universities in the country on account of exorbitant fees. The author argues that these campaigns were underscored by calls to decolonise education, but that academics and intellectual elites hijacked the decolonisation calls by appealing to intellectual debates that excluded student voices and their experiences. By contextualising the call for decolonisation from the actual experiences of an African student under the exclusionist university system, the author calls for decolonisation as it has been reinterpreted from the elitist academic theorisation perspective. Using the tradition of ethnographic thick description, the author studies the case of one postgraduate student highlighting the maltreatment that students 
suffer and how this continues to dehumanise African students. By this exposure, the author puts into perspective what exactly needs to be done to free students from a colonised system, and he thus underscores the alienation of African students caused by persisting neo-colonial tendencies of a university system and suggests ways in which academics can decolonise their contribution to students' experiences.

The next article by Francis B. Nymanjoh, is based on his Africa Day Memorial Lecture, at the Auditorium, Equitas Building, University of the Free State, Bloemfontein, Wednesday 22 May 2019 at 17:30. In his 'Ubuntuiism and Africa: Actualised, Misappropriated, Endangered, and Reappraised', he argues that the idea that human beings are bound to each other inextricably is at the heart of African agency. It draws on the African philosophy Ubuntu, with its roots in human incompleteness, sociability and inclusivity. Ubuntu's precepts and workings are severely tested in these times of rapid change, accelerated nimblefootedness, and multiple responsibilities. Africans negotiate their social existence between urban and rural life, continental and transcontinental realities, and all the market forces that influence relationships and loyalties. Between ideal and reality, dreams and schemes, how is Ubuntu actualised, misappropriated, and endangered? This talk unearths the intrigues and contradictions that go with inclusivity in Africa. Basing my argument on the ideals of trust, conviviality and support embodied in the concept of Ubuntu, I seek to demonstrate how the pursuit of personal success and even selfaggrandisement challenges these ideals, thus leading to discord in social relationships. Even as it is increasingly seriously tested by opportunism, Ubuntuism, sometimes a reality and sometimes an ideal, brings hope and redemption, and offers a feasible framework for participatory and inclusive emancipatory social change.

Oscar Eybers and Emma Paulet's contribution takes the title, 'Embedding Ubuntu Principles into Dialectic Argumentation and Academic Writing', to analyse first-year science students' understandings and experiences of ubuntu epistemology in an argumentation-focused, academic writing module named LST 110 . The authors critically analysed students' reflective journal entries on translanguaging to assess their experiences of mastering argumentative concepts in a multilingual environment. Their analysis of the narratives of most of the participants in this study indicated that students' understanding and appreciation of ubuntu as practised through translanguaging increased. They found that students described ubuntu as an 
enabling principle for academic argumentation and teamwork across cultural borders. The authors advocate for the African epistemology of ubuntu as an effective pedagogical tool for advancing dialectic arguments in multilingual science classrooms and in academic writing.

Kutenda Trinos and Ronicka Mudaly titled their article, 'Exploring Possibilities for Including Indigenous Knowledge into the Biology Teacher Education Curriculum: Leveraging Insights from Karanga Knowledge Holders'. They argue that the dearth of African knowledge and African methods of knowing in formal education perpetuates the colonial agenda that Africa and her people have little to contribute to the global knowledge repository. In this context, they seek to disrupt the ontological exiling of the colonised from education, in particular, pre-service teacher education, by shifting our gaze towards the affordances of African Indigenous Knowledge (AIK) in the present context of the COVID-19 pandemic. We depart from the epistemological centre, which is dominated by Euro-Western knowledge traditions, and explore marginalised epistemic sites, by tapping into knowledge/s of African traditional healers. We generated data through interviews using Zoom with five purposively selected indigenous knowledge holders from the Karanga community in Zimbabwe, to obtain their views about the causes and management of infectious diseases, including COVID-19. We found that from an African perspective, the outbreak of COVID-19 is attributed to spiritual explanations where illness is a punishment from the ancestors for the wrongs done by the living. Dumwa/mutimwi (a string from a special tree) tied to the neck, wrist, or waist, is used as a preventive measure against diseases. Quarantining and isolation are a common practice used by the African communities to prevent the spread of viral diseases. Consumption of traditional foods and medicines are encouraged to manage effects of viral infections. Parts of plants such as Zumbani and Mufandichimuka are used to treat symptoms caused by influenza viruses. These and other insights from Karanga indigenous knowledge holders will be embedded in the teacher education biology curriculum. By re-centering knowledges from the Global South, the peripherality of AIK in teacher education will be challenged.

Thenjiwe Meyiwa and Madoda Cekiso look into 'An Africanised and Gender Sensitive Curriculum as a Social Justice and Educational Human Right Owed to all South Africans', to discuss the South African education system's emergence after the dismantlement of the divided subsystems which operated along racial and ethnic-linguistic lines, which had 
transpired under the apartheid oppressive government era. Not only was the system characterised by segregation, but by a curriculum that was explicit in enforcing different educational opportunities for South Africans depending on their racial classification. The curriculum of the oppressed was designed by the oppressors who had a cultural background different to that of Africans, and irrelevant, as it did not empower Africans by enabling them to determine their own indigenous African educational framework. By making a historical context for educational equity in the post-apartheid South Africa, the article makes a submission that the inclusion of local and indigenous knowledge systems in the South African education system, and an explicitly gender sensitive curriculum, is necessary in order to make education relevant to the communities it is supposed to serve.

Thandeka Yasmeen Ndaba and Maheshvari Naidu remind us that African women's bodies and sexualities are one of the tropes that one can approach the complex and multiple entanglements of decoloniality and coloniality imbricated with cultural entanglements of values and expectations on African women's sexuality and sexual pleasure. In their article, they approach coloniality as a power that imposes alien values and expectations, including values and expectations on sexual pleasure for women. In '(Re)Claiming African Women's Sexual Agency: Male Circumcision and Women's Pleasure', their qualitative study is a study in reclamation and reinserting African women's sexuality more visibly into African discourse.

Debates about decolonisation in general and decolonising the curriculum in higher education are often focused on theoretical critiques including epistemicide, linguicide, historicide, alienation, and dismemberment. As important as these contributions are, they seldom offer integrated strategies for those who are tasked with decolonising the curriculum in the university context or those who must teach individual courses, and who would like to do so from a Southern, decolonised perspective. In this paper we adopt a pragmatic, critical, and realist approach and hover above many of these constituent debates to offer a consolidated approach to how the (social science) curriculum in higher education might be decolonised practically and pragmatically. In their 'Decolonising the Social Sciences Curriculum in the University Classroom: A Pragmatic-realism Approach', Sharlene Swartz, Anye Nyamnjoh, and Alude Mahali draw on ideas from Freire, NdlovuGatsheni, Mbembe, and Bhambra, and ask: 1) what are the stakes of the struggle towards decolonising the curriculum 2) what are the blind spots 
needed to be overcome in the journey? and 3) what practical and incremental steps can be taken, regardless of your own positionality, to achieve a decolonised curriculum. Practically, we outline a number of theses that we have adopted in our own teaching. These centre around input and expertise (who should be decolonising the curriculum, who should be teaching?); content and canon (what should be taught, what excluded, and whether material from the centre should be taught at all, and if so, when?); institutions and pedagogies of decolonised education (how should material be taught, how might the hidden curriculum of the institution in which it is taught be made explicit), and the role of theory in decolonised education (what is the aim of decolonised education?). It is envisioned that packaged together, these theses offer key considerations for those tasked with thinking about and teaching a decolonised curriculum.

In 'Decolonization Deferred: Seretse Khama, Ian Khama's Presidency and the Historical Deradicalization of 'Culture' as a Tool for Resistance in Botswana', Sethunya Tshepho Mosime's article takes a historical approach to explore why, since from the first President of Botswana, Sir Seretse Khama in 1965, and especially during the Presidency of his son, Seretse Khama Ian Khama in 2008, the discourse of decolonisation never found strong traction in Botswana. I suggest that the older Khama drew from the notion of culture - to invent a neo-liberalism friendly cultural hegemony that would help maintain British support for the newly independent and economically fragile state. It would also maintain the dominance of the ruling Botswana Democratic Party, and much later lay a fertile ground for the younger Khama to be 'culturally' accepted to take up the Presidency. Culture, defined in varying ways by the two Khamas, has been useful for entrenching and normalising inequalities, where Botswana is one of the most unequal societies in the world, with high income inequalities, high levels of gender-based violence and some of the lowest numbers of women in political leadership in Africa. It has also been useful to entrench and normalise low levels of civic participation and resistance without any strong demands for decolonisation, a fertile environment for neo-liberalism and its economic growth without transformation of livelihoods.

Christian, John Makgala, Andy Chebanne, Boga Thura Manatsha and Leonard L. Sesa discuss the 'The Discourse of Tribalism in Botswana's 2019 General Elections'. from the perception of Botswana's much touted, traditionally peaceful presidential succession experienced, they focus on an 
'upheaval' after the transition on 1 April 2019 as a result of former President, Ian Khama's public fallout with his handpicked successor, Mokgweetsi Masisi. This led to the former president making a robust campaign to dislodge his successor from power, and culminating in the formation of a new opposition political party and the mobilisation of the Bangwato tribal territory, of which Khama is kgosi (paramount chief), for the 2019 general elections. Two perspectives emerged on Khama's approach, which was labelled 'tribalism'. One school of thought was that the Westernised and bi-racial Khama was not socialised sufficiently into Tswana culture and tribal life to be a tribalist, and was using colonial-style strategy of divide-and-rule cunningly to achieve his agenda. The second school of thought argued that Khama was hell-bent on stoking 'the African curse, also known as tribalism', to bring Masisi's government to its knees. The authors observe that Khama's approach was not entirely new but only much bigger in scale, as 'tribalism' has been widely used by individual politicians as a short-term strategy, but hardly paid dividends.

Malebogo Kgalemang's article 'Ethnic Reasoning and the Making of the Nation of Botswana' explores the imagined nation of Botswana within the nation and imperialism and the nation and narrations frameworks that have been discussed by other authors. The author starts with the reflection by Anderson's Imagined Communities who weaves an 'anthropological spirit' in his definition of a nation, and asserts that the nation is 'primarily an idea', an 'imagined political community' that is 'both inherently limited and sovereign'. She analyses the noun 'Imagination' as a key to understanding how a nation evolves, how it self-conceptualises and essentially how it is imagined as a state. She affirms Anderson's view that a nation imagining itself is an important defining trait since 'members of even the smallest nation will never know most of their fellow members, meet them, or even hear of them, yet in the minds of each lies the image of their communion'. Therefore, 'imagination' becomes crucial to a nation's unity, nationhood, and nationalism. She pursues the view that the concept of imagination should not be construed to mean false but 'remains a mentalist, subject category'.

Walter Gam Nkwi's 'Britain, UN and the Decolonisation of British Southern Cameroons: The Past Foundations of the Present day Ambazonia War of Independence in Cameroon' has two primary arguments. First it argues that the Ambazonian war was created partly by the process of decolonisation initiated by the erstwhile British territory in complicity with the United Nations. Secondly, the paper maintains that it was 
the failure of the post-colonial state elite to forge a sustainable and viable nation in Cameroon that led to the war. The two arguments are complementary - the failure of the post-independent state elite is as a consequence of the continuous manipulation of the former colonial powers. Archival files mined from the Buea National Archives and secondary sources from libraries in Cameroon and Europe were used as evidence for my argument. From these sources the paper concludes that the charter of the UN trusteeship which was given to Britain as a colonial power was never executed to the end. Thus, it was a dismal failure both to the United Nations and to Britain, and by extension, to the post-colonial government. The article hopes to contribute to the body of knowledge in the field of decolonisation. It provides some evidence of how Britain and France have played an enormous role in dividing people within the Cameroon nation-state that had future repercussions in how people are marginalised in the present. The article highlights a failure of Britain, the $\mathrm{UN}$, and the post-colonial state, which have failed to initiate any peacebuilding after colonialism and decolonisation had torn the country apart.

Megan Robertson's article, 'Toward an Indecent Queer Activism: Interrogating the Relationship between Christianity, Civilised Whiteness and Queer Politics in South Africa', discusses the history of queer politics in South Africa as framed by tensions between the struggle for gay rights and black freedoms. The author looks into Christian and cultural beliefs and discourses that underlie these past tensions as they continue to inform black resistance to the plight of gay black men, and white gay activists' ambivalence to black freedom. The author states that these same religious influences, along with politics of power, largely exclude women and trans-persons from featuring in either side of the debate, and argues that contemporary gay politics has largely developed as a response to the policing of white gay men and in many ways has not developed into an intersectional queer activism. e further argues for the development of an 'indecent' activism that challenges dominant narratives that frame queer activism in South Africa today. He adds nuance to existing critiques of gay politics of contemporary South Africa by analysing the construction of 'civilised' white sexuality within the political discourse of South Africa, and draws on a queer and decolonial analytic to review literature which has explored the varied agencies of religious, black, and trans queer people.

Busani Maseko and Prisca Matunge look into, 'Language Ideologies and Language Practices in Health Services: Patients' Experiences in Post- 
colonial Zimbabwe'. They argue that language is the most important means through which patients access health care services and health information. Within the current language policy studies, the authors look critically into the decolonial discourses and scholarship that tended to begin and end with the politics and problematisation of the colonially inherited English language as a 'recurring decimal' in education, the media. and other public spaces. The discussion of language experiences of patients who had sought medical assistance in selected hospitals in Zimbabwe previously expose how doctors' and nurses' language practices are a reproduction of structures and orders of power. The author's view is that these power-inflected practices foreground the Shona language as the natural, uncontested alternative to English, to the detriment of other African indigenous languages and their speakers. They further attempt, through the triangulation language policy and the concept of symbolic domination, to show how doctors' and nurses' preference for the use of Shona in clinical encounters with non-Shona patients validates the pervasive Shona hegemonic ideology and domination. They argue that the endeavour to decolonise the Zimbabwean linguistic ecology has degenerated into a new linguistic order, ?bordering on unofficial proscription and exclusion of other languages, and recommend a rethink of language policy in health, to embrace professional interpreter services and deployment of language concordant health practitioners to foster inclusive health services provision.

Nathan Mnjama's 'Migrated Archives: The Unfinished Business', demonstrates how archives are a valuable resource to national identity, and how they have been used as tools for the accomplishment of various purposes in society, some good and others evil, as in the case colonising powers which failed to bequeath archival collections to the newly independent states when handing over power to the incoming governments, thus denying the communities they had colonised valuable information resources documenting their cultural and historical experiences under the colonial rule. He argues that as African states gained independence, they began to realize that they had not only inherited weak archival institutions or no archival institutions at all, but that valuable records were missing, had been destroyed, or for various reasons not available locally. The article argues that building strong archival institutions meant that they had to embark on a major task of locating the missing records locally and abroad as access to records and the information they contain is a good tool to achieving accountability, transparency, and good governance. 
Ayub Sheik's article on, "A man is a tale that is told": Decolonisation and the Afrocentric Curriculum', discusses the African consciousness that has been wholly subsumed by western ideology and resurfaces only in misrecognition and habitual disavowal. The author argues that by valorising everything European, Africa has a history of haplessly succumbing to the seductions of western rationality and perspectives. This, the author argues, led to the denial and erasure of self and culture, and in its place, the morbid African has birthed, confronting his othering in self-defeating acquiesce and accepting his servile status as natural and ordained. Sheik argues that there is no ready panacea for centuries of exploitation, domination, and telling to. He suggests that one way to counter these ideological formations is to provide pathways to recognise the self by the rekindling of the myth, folklore, and aphorisms long extinguished on the altar of western education. Sheik explores African stories as artefacts that may shape consciousness, and remind us of cultural wisdom rendered invisible and barbaric by colonial authority, and focuses attention on an African cantered morality, value system, and school Africa in the inherent dignity of being human and African. In Sheik's view, the abundance of tales that promote social cohesion, the adherence to rituals, the rule of law, as well as survival over seemingly insurmountable odds, provide lessons that may be modelled onto the coronavirus pandemic in an African centred advocacy. Recruiting the resources of bibliotheraphy and decolonising scholarship, Sheik enthuses over African narratives that celebrate Africa's own conundrums, and engages with lessons to survive the coronavirus pandemic in an Afrocentric intertext, and makes it the first and necessary steps of emancipation from the shackles of western epistemologies and hegemony.

The decolonization-Africanization debate cannot be exhausted or concluded in one volume of a journal. However, what this collection of articles achieves is to rekindle the fire and recommit African leaders and policy makers to keep the focus on Africanization and decolonization. The true and democratic liberation of Africa will be found therein. As the pioneers of this agenda have experienced, it is not a question of political ideological framework, but a question of whether Africans have faith in what they want to be, and how they want to get to what they want to be. So much is at stake, and the contributors are showing that something is in motion, and to take Africans from their wretched condition to a true emancipation, economically, politically, philosophically, and linguistically. 


\section{References}

Fanon, F. [1952] 2008. Peau noire, masques blancs. Paris : Seuil. Black Skin, White Masks. Philcox, R. (trans.). New York: Grove Books.

Fanon, F. [1961] 2005. Les damnés de la terre. Paris : Maspero. The Wretched of the Earth. Philcox, R. (trans.). New York: Grove Books.

Loomba, A. 2015. Colonialism/ Postcolonialism. $3^{\text {rd }}$ Edition. The New Critical Idiom. London \& New York: Routledge, Taylor \& Francis Group.

Mbembe, A. 2016. Decolonising the University: New Directions. Arts and Humanities in Higher Education 15,1: 29 - 45.

Oelofsen, R. 2015. Decolonisation of the African Mind and Intellectual Space. Phronimon 16,2: 130 - 146.

Quijano, A. 2007. Coloniality and Modernity/ Rationality. Cultural Studies 21, 2-3: $168-178$.

Otunnu, O. 2015. Mwalimu Julius Kambarage Nyerere's Philosophy, Contribution, and Legacies. African Identities 13,1: 18 - 33.

Nkurumah, K. 1964. Consciencism: Philosophy and Ideology for Decolonization. New York: Monthly Review Press.

Poe, Z. 2010. Kwame Nkrumah's Contribution to Pan-Africanism: An Afrocentric Analysis. Los Angeles: University of Sankore Press.

Vivian Ojong

Professor of Anthropology Dean and Acting Head of School of Social Sciences University of KwaZulu-Natal Ojong@ukzn.ac.za

Andy Chebanne Professor of Linguistics Department of French University of Botswana CHEBANNE@UB.AC.BW

Maheshvari Naidu

Professor in Anthropology Academic Leader of Research University of KwaZulu-Natal naiduu@ukzn.ac.za 